\title{
PHYSICALLY-BASED MODELLING OF THE POST-FIRE RUNOFF RESPONSE OF A FOREST CATCHMENT IN CENTRAL PORTUGAL: USING FIELD VERSUS REMOTE SENSING BASED ESTIMATES OF VEGETATION RECOVERY
}

\author{
Christel M. Van Eck ${ }^{1,2}$, Joao P. Nunes ${ }^{1 *}$, Diana C. S. Vieira ${ }^{1}$, Saskia Keesstra ${ }^{3}$, Jan Jacob Keizer ${ }^{1}$ \\ ${ }^{1}$ CESAM and Department Environment and Planning, University of Aveiro, Aveiro, Portugal \\ ${ }^{2}$ Department of Geoscience, Environment, and Society, CP 160/02, Université Libre de Bruxelles, 1050 Brussels, Belgium \\ ${ }^{3}$ Soil Physics and Land Management Group, Wageningen University, Wageningen, the Netherlands \\ Received: 16 February 2016; Revised: 26 February 2016; Accepted: 26 February 2016
}

\begin{abstract}
Forest fires are a recurrent phenomenon in Mediterranean forests, with impacts for human landscapes and communities, which must be understood before they can be managed. This study used the physically based Limburg Soil Erosion Model (LISEM) to simulate rainfall-runoff response, under soil water repellent (SWR) conditions and different stages of vegetation recovery. Five rainfall-runoff events were selected, representing wet and dry conditions, spread over two years after a wildfire which burned eucalypt and maritime pine plantations in the Colmeal experimental micro-catchment, central Portugal. Each event was simulated using three Leaf Area Index (LAI) estimates: indirect field-based measurements (TC-LAI), NDVI-based estimates derived from Landsat-5 TM and Landsat-7 ETM+ imagery (NDVI-LAI), and the LAI of a fully restored canopy to test model sensitivity to interception parameters. LISEM was able to simulate events in relative terms but underestimated peak runoff $\left(r^{2}=0 \cdot 36\right.$, mean error $=-31 \%$, and NSE $\left.=-0 \cdot 15\right)$ and total runoff $\left(r^{2}=0 \cdot 52\right.$, mean error $=-15 \%$ and NSE $=0.09$ ), which could be related to the presence of SWR or saturated areas, according to pre-rainfall soil moisture conditions. The model performed better for individual hydrographs, especially under wet conditions. Modelling the full-cover scenario showed minor sensitivity of LISEM to the observed changes in LAI. NDVI-LAI data gave a close to equal model performance with TC-LAI and therefore can be considered a suitable substitute for ground-based measurements in post-fire runoff predictions. However, more attention should be given to representing pre-rainfall soil moisture conditions and especially the presence of SWR. Copyright @ 2016 John Wiley \& Sons, Ltd.
\end{abstract}

KEY WORDS: post-fire hydrology; vegetation recovery; remote sensing; runoff modelling; LISEM

\section{INTRODUCTION}

Wildfires are a frequent phenomenon in the European Mediterranean region (Shakesby, 2011). The heating of soil by fire can change various physical, chemical, and biological characteristics such as water repellency (Doerr et al., 2000; Malvar et al., 2015), aggregate stability (Mataix-Solera et al., 2011), organic matter and nutrient content (De la Rosa et al., 2012), and composition of microbial communities (Certini, 2005). Clogging of soil pores with ashes, fire-enhanced or -induced soil water repellency, and soil surface sealing by enhanced raindrop impact may cause reduced infiltration and, thus, affect the hydrological response (Shakesby, 2011; Bodí et al., 2013; Malvar et al., 2013; Bodí et al., 2014; Vieira et al., 2015). Depending on burn severity, vegetation cover can be damaged or burnt completely, resulting in a decrease in ground coverage and therefore also in interception, storage capacity, and flow resistance (Ferreira et al., 2005, 2008; Esteves et al., 2012; Keesstra et al., 2014). These changes to soils and vegetation influence the hydrological and erosion response of the burnt sites

*Correspondence to: João Pedro Nunes, Department of Environment and Planning, University of Aveiro, Campus Universitário de Santiago, 3810193 Aveiro, Portugal.

E-mail: jpcn@ua.pt
(Ferreira et al., 2008, 2015; Malvar et al., 2013; Malvar et al., 2011; Martins et al., 2013; Prats et al., 2013, 2015). These changes occur during a period referred to as the window of disturbance, which can last from 3 months till several years after the fire while soils and vegetation recover, and are linked to downstream risks because of flooding, silting up of reservoirs and pollution of surface water bodies (Shakesby \& Doerr, 2006; Shakesby, 2011).

Wildfire occurrence has increased in the Mediterranean in the past decades (Shakesby, 2011), stressing the need for accurate post-fire hydrological catchment response predictions in order to estimate flood risk and assess the potential impact of mitigation measures. Models have often been used for prediction and management in Mediterranean agro-forestry watersheds (Keesstra et al., 2009; Nunes et al., 2013; Bisantino et al., 2015; Borrelli et al., 2015). However, there are not many studies on post-fire runoff and erosion modelling (Moody et al., 2013).

In fact, modelling post-fire hydrological response of a burnt catchment can still constitute a challenge because hydrological processes in burnt catchments are still poorly understood, due to the interactions between catchment properties, fire-driven vegetation and soil changes, and post-fire forestry operations such as salvage logging or bench terracing, which are highly variable in time 
during the window of disturbance (Shakesby, 2011; Malvar et al., 2013; Moody et al., 2013). Process understanding has been hampered by the lack of post-fire catchment-scale studies (Shakesby, 2011).

Studies applying continuous models to Mediterranean burnt areas have pointed to the importance, for adequate runoff simulations, of representing vegetation destruction and recovery (Soto \& Díaz-Fierros, 1998; Morrison \& Kolden, 2015; Moussoulis et al., 2015) and soil water repellency (Esteves et al., 2012; Vieira et al., 2014). For predictions during individual large storms, Chen et al. (2013) have shown the importance of simulating the transition between saturation-excess to infiltration-excess runoff generation, which could also reflect repellency conditions; few studies have focused on vegetation recovery at this scale.

The recovery of vegetation is generally considered one of the controlling factors in restoring pre-fire hydrological conditions (Shakesby \& Doerr, 2006; Mayor et al., 2007). Several studies have successfully quantified post-fire recovery using the Normalised Difference Vegetation Index (NDVI) derived from satellite imagery (Viedma et al., 1997; Van Leeuwen et al., 2010; Vogelmann et al., 2011). NDVI has been found to correlate well with Leaf Area Index (LAI; Lillesand et al., 2008), which is commonly used in process-based rainfallrunoff models to represent land cover (Jonckheere et al., 2004). The use of remote sensing images for vegetation monitoring and its integration in post-fire runoff modelling has also been proposed to facilitate and enhance post-fire runoff response prediction (Drake \& Vafeidis, 2004; Vafeidis et al., 2007; Morrison \& Kolden, 2015). On the other hand, there are still few applications incorporating soil water repellency in post-fire models (Nunes et al., 2016).

The aim of this study was to assess the performance of a process-based rainfall-runoff model, in this case the Limburg Soil Erosion Model (LISEM; De Roo et al., 1996), in a post-wildfire environment in the Mediterranean Basin, using both ground- and space-based measurements of LAI. The study area was a micro catchment in Central Portugal, monitored over two years after a fire that burnt almost the total area. Ground-based LAI measurement methods were indirect and related with time-consuming groundcover monitoring at several small scale plots, while space-based measurements used NDVI from Landsat imagery and established an NDVI-LAI relationship for local vegetation. Model performance was also assessed according to different conditions of soil water repellency measured in the field.

\section{MATERIALS AND METHODS}

\section{Study Area}

The study area was located near Colmeal in the Coimbra District of north-central Portugal (coordinates: $40^{\circ} 08^{\prime} 46^{\prime \prime}$ $\left.\mathrm{N}, 7^{\circ} 59^{\prime} 35^{\prime \prime} \mathrm{W}\right)$. On the 27 August 2008, a wildfire burnt a forest area of around 70 ha, including the Colmeal experimental catchment of approximately 11 ha. Colmeal lies in a transition zone between an Atlantic and a Mediterranean climate. Precipitation varies between 1400 and $1600 \mathrm{~mm}$. The soil originates from schist parent material, corresponding to predominantly humic Cambisols according to the FAO2006 classification (De la Rosa et al., 2012). The Colmeal catchment was dominated by eucalypt plantations (Eucalyptus globulus Labill), together with a pine stand (Pinus pinaster Ait.) (Figure 1). Most of the eucalypt plantations had three different types of pre-fire land management operations: contour ploughing (unit III), terracing (unit IV), and downslope ploughing (unit V). Following the wildfire, parts of the catchment were logged and terraced, whereas other parts were not intervened. The area was intensively monitored after the wildfire, with research done on changes potentially affecting hydrological behaviour such as soil properties (Otero et al., 2015), soil organic matter (De la Rosa et al., 2012), vegetation recovery (Maia et al., 2012), runoff toxicity (Campos et al., 2012), and post-fire runoff and erosion control (Prats et al., 2013).

\section{LISEM}

LISEM is a process-based hydrological and soil erosion model that was developed to simulate runoff and erosion from individual rainfall events at the catchment scale (De Roo et al., 1996). In LISEM, LAI is used to estimate maximum canopy storage capacity as well as a correction factor
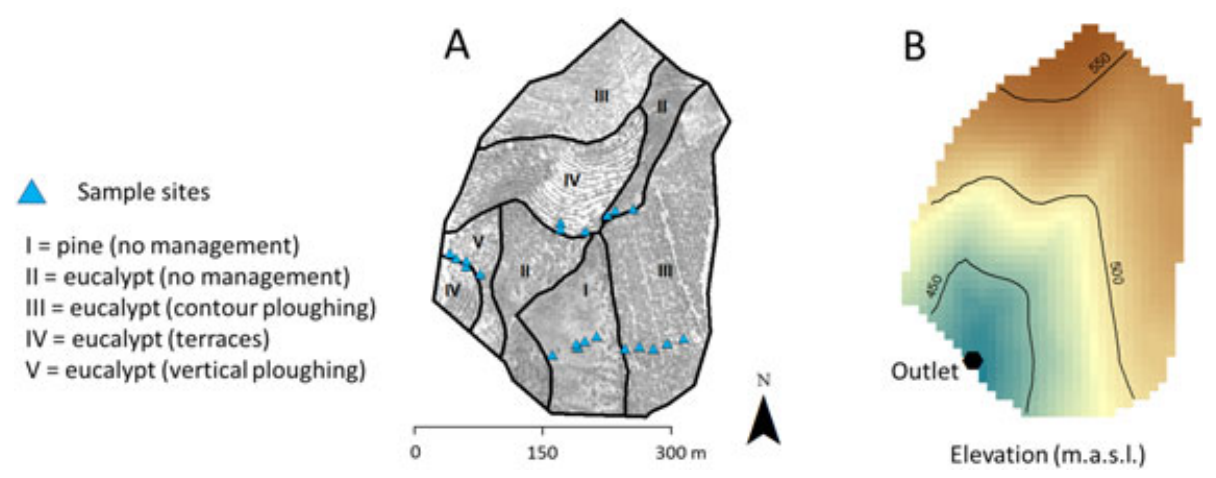

Figure 1. Catchment characteristics of Colmeal: land units, land use and management characteristics, and transect locations (A), and elevation (m.a.s.l.), contour lines with 50-m interval and the location of the outlet (B). 
for vegetation density in the empirical interception equation by Aston (1979):

$$
I_{\text {cum }}=c_{p} * S_{\max } *\left(1-e^{-k_{S_{\max }}^{P_{\text {cum }}}}\right) .
$$

Where:

$I_{\text {cum }}=$ Cumulative interception $(\mathrm{mm})$

$c_{p}=$ Vegetation cover fraction (-)

$\mathrm{S}_{\max }=$ maximum canopy storage capacity

$$
=0.935+0.498 \cdot L A I-0.00575 \cdot L A I^{2} \text {. }
$$

$k=$ Correction factor for vegetation density (-)

$$
=0.046 \cdot L A I \text {. }
$$

$p_{\text {cum }}=$ Cumulative rainfall $(\mathrm{mm})$.

In turn, Equations 2 and 3 were proposed by HoyningenHuene (1983).

For modelling purposes, the catchment was subdivided in five land-cover/-management units (Figure 1B). The same soil type (humic Cambisol) was assumed for all five units.

Model parameters were determined by data collection in the field, literature study, or empirical analysis. Because LISEM was applied using the one-layer Green-Ampt infiltration equation with a 10-min time step, the associated soil parameters were saturated hydraulic conductivity (Ksat), average suction at the wetting front $(\psi f)$, and saturated soil moisture content $(\theta s)$. These were estimated by applying pedotransfer functions (Rawls et al., 1982; Saxton \& Rawls, 2006) to soil texture data from 22 sample points within the burnt area (Faria, 2009). The vegetation cover parameter ( $\mathrm{COV} \%$ ) was derived from 1- to 3-monthly field assessments in 2009 and 2010 that were carried out along a fixed transect in each of the five land units (Figure 1). Also soil depth $(d)$ and soil surface roughness $(R R)$ were measured along these transects, while the Manning's coefficient $(n)$ was estimated from this data (Dingman, 2008).

Rainfall was measured using three tipping-bucket rainfall gauges located within the catchment, and recorded at 10-min intervals. Stream flow was measured by recording water level in an H-type flume at 2-min intervals using an ultrasound water level sensor.

For this study, five rainfall events were selected over two years after the wildfire. The events had to occur during contrasting initial soil moisture conditions (dry vs. wet season) and when good-quality Landsat-5 TM or Landsat-7 ETM+ images were available.

The performance of LISEM was assessed by comparing simulated and measured stream flow using the Nash-Sutcliffe model efficiency coefficient (NSE; Beven, 2012) and the coefficient of determination $\left(r^{2}\right)$. Because LISEM does not simulate baseflow, it was extracted from streamflow using the automated baseflow separation technique proposed by Arnold et al. (1995).

Both event and within-event model performance were evaluated. Event performance concerned the events' total discharge (L) and peak runoff $\left(\mathrm{L} \mathrm{s}^{-1}\right)$, while within-event performance concerned the shape and timing of the hydrograph. Model performance was considered to be satisfactory when $r^{2}$ was above 0.36 and good when $r^{2}$ was above 0.75 , while an NSE of 0.5 was considered to indicate good model performance (Motovilov et al., 1999; Nunes et al., 2009).

As several soil parameters were derived from empirical pedotransfer functions, soil parameters were calibrated within the boundaries considered realistic for each parameter.

\section{Estimation of LAI}

In this study, LAI was determined by two different methods. The first method (TC-LAI), was based on field measurements of ground cover, which were then converted into LAI estimates using the light extinction coefficient following Deguchi et al. (2006):

$$
L A I=\left(\frac{-\operatorname{Ln}(1-G C)}{K}\right)+L A I_{p h e n} .
$$

Where:

$$
\begin{aligned}
& L A I=\text { Leaf Area Index }\left(\mathrm{m}^{2} \mathrm{~m}^{-2}\right) \\
& G C=\text { Ground cover }(-) \\
& K \quad=\text { Light extinction coefficient }(-) . \\
& L A I_{\text {phen }}=\text { Phenological Leaf Area Index }\left(\mathrm{m}^{2} \mathrm{~m}^{-2}\right) .
\end{aligned}
$$

Because re-sprouting eucalypt trees were not included in the ground cover measurements, their contribution to TCLAI was estimated based on the tree age at the time of each rainfall event. The resulting estimates were validated through comparison with previous studies (Valentini et al., 1995; Scurlock et al., 2001; Hoff et al., 2002) combined with local knowledge.

The second method (NDVI-LAI) used NDVI data from Landsat-5 TM and Landsat-7 ETM+ imagery with a spatial resolution of $30 \mathrm{~m}$, which were then converted into LAI estimates also using the light extinction coefficient and the semi-empirical approach described by Baret \& Guyot (1991). NDVI was derived from the reflectance values of bands 3 (red) and 4 (near-infrared NIR):

$$
N D V I=\frac{\rho^{N I R}-\rho^{R E D}}{\rho^{N I R}+\rho^{R E D}}
$$

Where:

$N D V I=$ Normalised Difference Vegetation Index $(-)$

$\rho^{N I R}=$ reflectance value of the near infrared band $(-)$

$\rho^{R E D}=$ reflectance value of the red band $(-)$.

Three Landsat-5 Thematic Mapper (TM) images of path 203/row 32 were used to estimate NDVI on 17 June 2009, 15 October 2009, and 24 November 2009, whereas two Landsat-7 ETM+ of path 204/row 32 were used to estimate NDVI on 21 June 2010 and 28 November 2010. A state of complete regrowth was reproduced by a Landsat-7 ETM+ image acquired on 1 March 2013. The Landsat images were corrected geometrically and radiometrically. Scene-to-scene variability was reduced by converting radiance into reflectance, following Chander et al. (2009) and Chander \& 
Markham (2003). The LAI-NDVI relation was derived from Baret \& Guyot (1991):

$$
L A I=-\left(\frac{1}{K}\right) \operatorname{Ln}\left(a\left(1-b^{*} N D V I\right)\right)
$$

Where:

$$
\begin{aligned}
L A I= & \text { Leaf Area Index }(-) \\
K= & \text { Light extinction coefficient }(-) \\
a= & N D V I_{\infty} \text { limiting value of NDVI for large } L A I \text { values } \\
& (-) \\
b= & N D V I_{\text {soil }}-N D V I_{\infty}, \text { reflectance variation between the } \\
& \text { soil }\left(N D V I_{\text {soil }}\right) \text { and the infinite canopy }\left(N D V I_{\infty}\right)(-) .
\end{aligned}
$$

A light extinction coefficient $(K)$ of 0.45 and 0.42 was used for the pine stand and eucalypt plantations respectively, based on the authors' recommendations. This relationship was successfully tested by Viedma et al. (1997) for post-fire vegetation regrowth in a Mediterranean climate, where it was shown to be suitable for the early stages of post-fire vegetation recovery, with low NDVI values, because of its asymptotic behaviour.

\section{Soil Water Repellency}

Soil water repellency was measured according to the 'Molarity of Ethanol Droplet' test (MED; Doerr, 1998). During the first two years after the wildfire, repellency measurements were performed following the same experimental design as in Keizer et al. (2008). The measurements were done monthly at 5 equidistant point along 25 to $30-\mathrm{m}$ transects that were laid out from the bottom to the top of the slope at shifting positions across the slope. In data analysis, the nine ethanol concentrations used $(0,1,3,5,8.5,13,18$, 24 , and $36 \%$ ) were aggregated into five repellency severity classes. These classes were based on their frequency of occurrence and the classes typically used in the study region (Keizer et al., 2008; Santos et al., 2013): extremely water repellent $(\mathrm{E}: \geq 36 \%$ ), very strong water repellent (V: 18 to $36 \%$ ), moderate/strong water repellent (M: 8.5 to 18\%), wettable (W: 5 to $8 \cdot 5 \%$ ), and very wettable (VW: 0 to $5 \%$ ).

\section{RESULTS AND DISCUSSION}

\section{LAI Determination}

Figure 2 shows the results of TC-LAI (ground-based measurements, Equation 2) and NDVI-LAI (satellite-based measurements, Equation 4), while their spatial distribution is represented in Figure 3. Both methods revealed an initial increase in LAI with time, as vegetation quickly recovered after the fire. This was followed by a small dip in LAI during summer of 2010, which can be related to dry summer conditions, after which LAI quickly stabilised again. The TC-LAI showed lower initial values than NDVI-LAI at the start of vegetation recovery and, in contrast, higher values during the summer 2010 dip; variability was also much higher in TC-LAI than in NDVI-LAI. Eucalypt rendered overall higher LAI values with both estimation methods than pine, which is characteristic for their fast regrowth in burnt areas. Using Equation 2, this led to $S_{\text {max }}$ estimates between $1.4 \mathrm{~mm}$ in mid-2009 and $1.9 \mathrm{~mm}$ in late 2010 .

\section{Soil Water Repellency}

Throughout the study period, soil water repellent (SWR) occurred in both the pine and eucalypt stands, but tended to be stronger and more persistent in the latter, similar to what was reported by Doerr et al. (1996) and, for long unburnt stands, by Keizer et al. (2005) and Santos et al. (2013). In 2009, SWR followed the expected patterns (Keizer et al., 2008; Malvar et al., 2015) with low values in winter when soils were wetter, and high values in spring, summer, and autumn when soils were drier. In 2010, however, repellency in the pine stand was much lower than in the first year, although still stronger in the dry seasons; while in the eucalypt stand it increased throughout the year. Vieira (2015) proposed that such changes could be related with post-fire SWR evolution, rather than with soil moisture conditions; the higher values in 2009 than in 2010 could indicate the initial enhancement of SWR by fire followed by its slow disappearance, as also observed by Tessler et al. (2008).
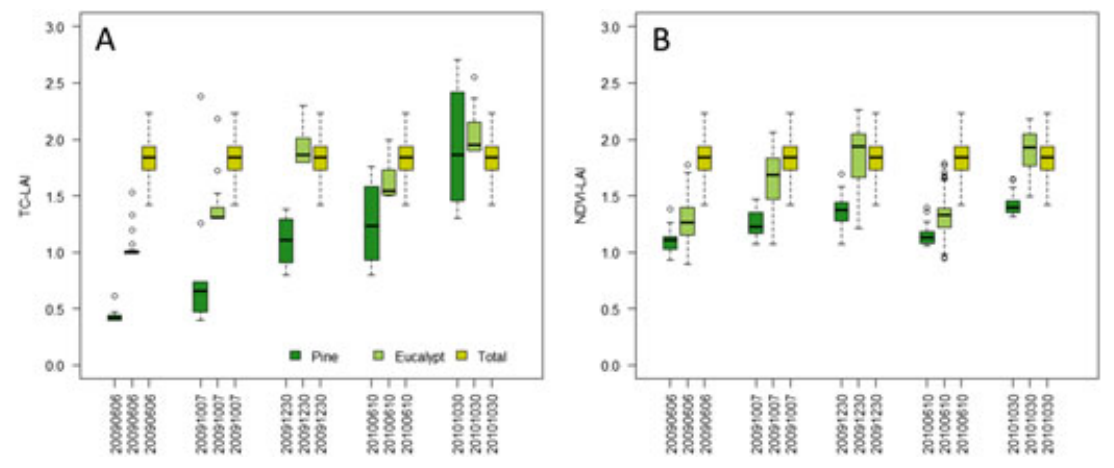

Figure 2. Statistical distribution of ground-based LAI measurements for Pinus pinaster Ait. cover and Eucalyptus globulus Labill. cover over time, using the TC-LAI relation (A) and the NDVI-LAI relation (B). Including the statistical distribution of the full cover LAI values for comparison. 


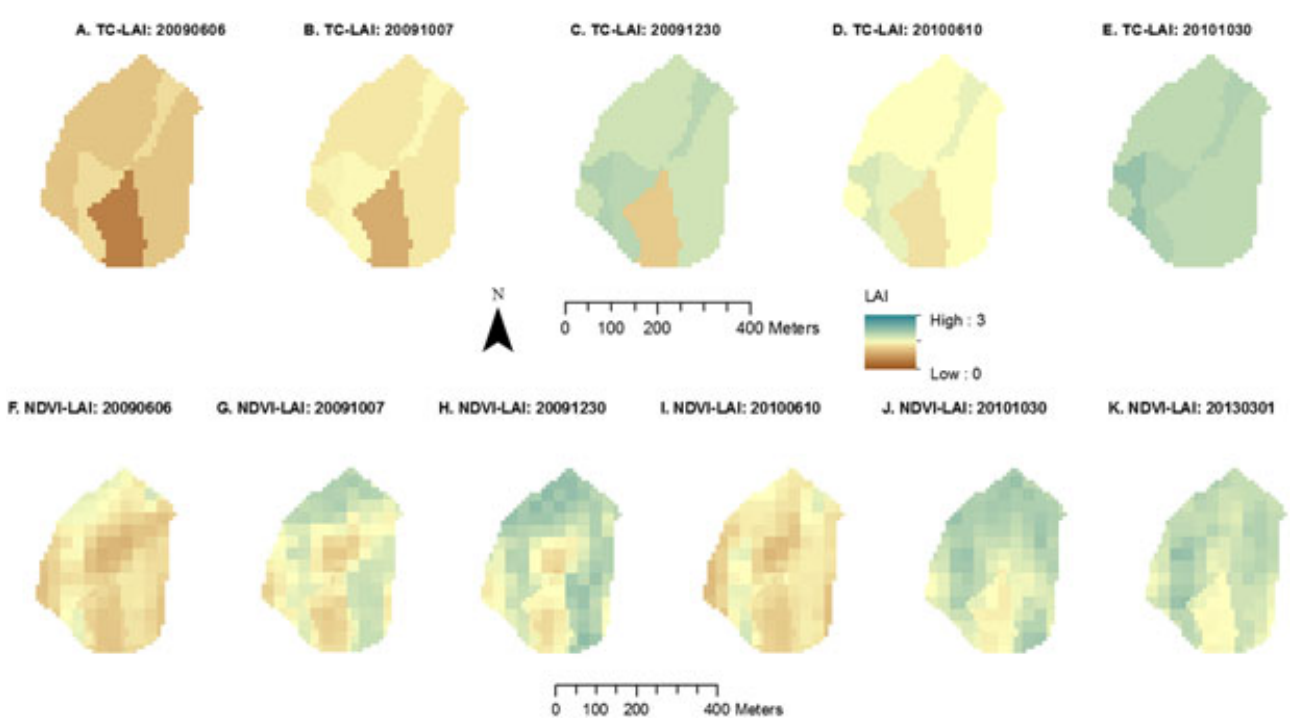

Figure 3. Spatial distribution of ground-based LAI measurements for Pinus pinaster Ait. cover and Eucalyptus globulus Labill. cover over time, using the TC-LAI relation (A to E) and the NDVI-LAI relation ( $\mathrm{F}$ to $\mathrm{K}$ ).

\section{Implementation of LISEM}

Table I gives the ranges of the field-measured values for groundcover $(\mathrm{COV} \%)$, random roughness $(\mathrm{RR})$, Manning's $\mathrm{n}(n)$, and soil depth $(d)$ and the estimated values for the soil parameters related to the Green-Ampt one-layer method of LISEM. Rainfall input data for each event is given in Table II. Total streamflow was clearly related with total rainfall, even though the difference between the two largest events was probably also related with catchment wetness, as expressed by initial baseflow. In contrast, peak streamflow seemed to be equally related with total rainfall and average rainfall intensity, but not with maximum rainfall intensity. The event with the highest streamflow was also the one with the lowest SWR conditions.

\section{Event Predictions}

Figure 5 shows the performance of LISEM for peak and total runoff prediction. LISEM performed worse in predicting runoff peak than total runoff; the coefficient of determination was satisfactory in both cases, although better for total runoff, but

Table I. LISEM input parameters

\begin{tabular}{|c|c|c|c|c|c|}
\hline Input & Abbreviation & Unit & Pine & Eucalypt & Source \\
\hline Plant cover & $\mathrm{COV} \%$ & Fraction & $0-0.2275$ & $0-0 \cdot 115$ & Field \\
\hline Random roughness & $R R$ & $\mathrm{~cm}$ & $2 \cdot 11$ & $1 \cdot 84-3 \cdot 91$ & Field \\
\hline Porosity & $\theta s$ & $\mathrm{~cm}^{3} \mathrm{~cm}^{-3}$ & $0 \cdot 2592( \pm 0 \cdot 0158)$ & $0 \cdot 5544( \pm 0 \cdot 0078)$ & Saxton \& Rawls (2006) \\
\hline Initial soil moisture content & $\theta i$ & $\mathrm{~cm}^{3} \mathrm{~cm}^{-3}$ & $0 \cdot 2876( \pm 0 \cdot 0178)$ & $0.5456( \pm 0 \cdot 059)$ & Saxton \& Rawls (2006) \\
\hline Soil water tension at wetting front & $\psi f$ & $\mathrm{~cm}$ & $11 \cdot 01$ & $11 \cdot 01$ & $\begin{array}{l}\text { Rawls et al. (1982); } \\
\text { Chow et al. (1988) }\end{array}$ \\
\hline Soil depth & $d$ & $\mathrm{~mm} \mathrm{~h}^{-1}$ & 30 & $100-300$ & Field \\
\hline Manning's $n$ & $n$ & - & $0 \cdot 06$ & $0.035-0.05$ & Dingman (2008) \\
\hline
\end{tabular}

Table II. Characteristics of rainfall events. Event codes represent the date of each event in the format year + month + day

\begin{tabular}{|c|c|c|c|c|c|c|c|}
\hline $\begin{array}{l}\text { Event } \\
\text { code }\end{array}$ & $\begin{array}{c}\text { Total } \\
\text { rainfall } \\
(\mathrm{mm})\end{array}$ & $\begin{array}{l}\text { Duration } \\
\text { (hh:mm) }\end{array}$ & $\begin{array}{l}\text { Average rainfall } \\
\text { intensity }\left(\mathrm{mm} \mathrm{h}^{-1}\right)\end{array}$ & $\begin{array}{c}\left.\text { Max. } 10 \mathrm{~min}^{-1}\right) \\
\text { intensity }\left(\mathrm{mm} \mathrm{h}^{-1}\right)\end{array}$ & $\begin{array}{c}\text { Initial } \\
\text { baseflow } \\
\left(\mathrm{Ls}^{-1}\right)\end{array}$ & $\begin{array}{l}\text { Total surface } \\
\text { runoff }(\mathrm{L})\end{array}$ & $\begin{array}{l}\text { Runoff peak } \\
\left(\mathrm{L} \mathrm{s}^{-1}\right)\end{array}$ \\
\hline 20090606 & $8 \cdot 2$ & $01: 50$ & $4 \cdot 47$ & $40 \cdot 80$ & $3 \cdot 30$ & $26254 \cdot 13$ & $31 \cdot 34$ \\
\hline 20091007 & $15 \cdot 2$ & $02: 20$ & $6 \cdot 51$ & $22 \cdot 80$ & 1.43 & 40955.92 & $27 \cdot 13$ \\
\hline 20091230 & 16 & $04: 10$ & $3 \cdot 84$ & $26 \cdot 00$ & 14.59 & $65100 \cdot 26$ & $22 \cdot 11$ \\
\hline 20100610 & $5 \cdot 6$ & 01:40 & $3 \cdot 36$ & $28 \cdot 80$ & $4 \cdot 37$ & $5129 \cdot 00$ & $2 \cdot 80$ \\
\hline 20101030 & $22 \cdot 6$ & $02: 40$ & 8.48 & $44 \cdot 40$ & $3 \cdot 87$ & $57376 \cdot 88$ & $27 \cdot 65$ \\
\hline
\end{tabular}



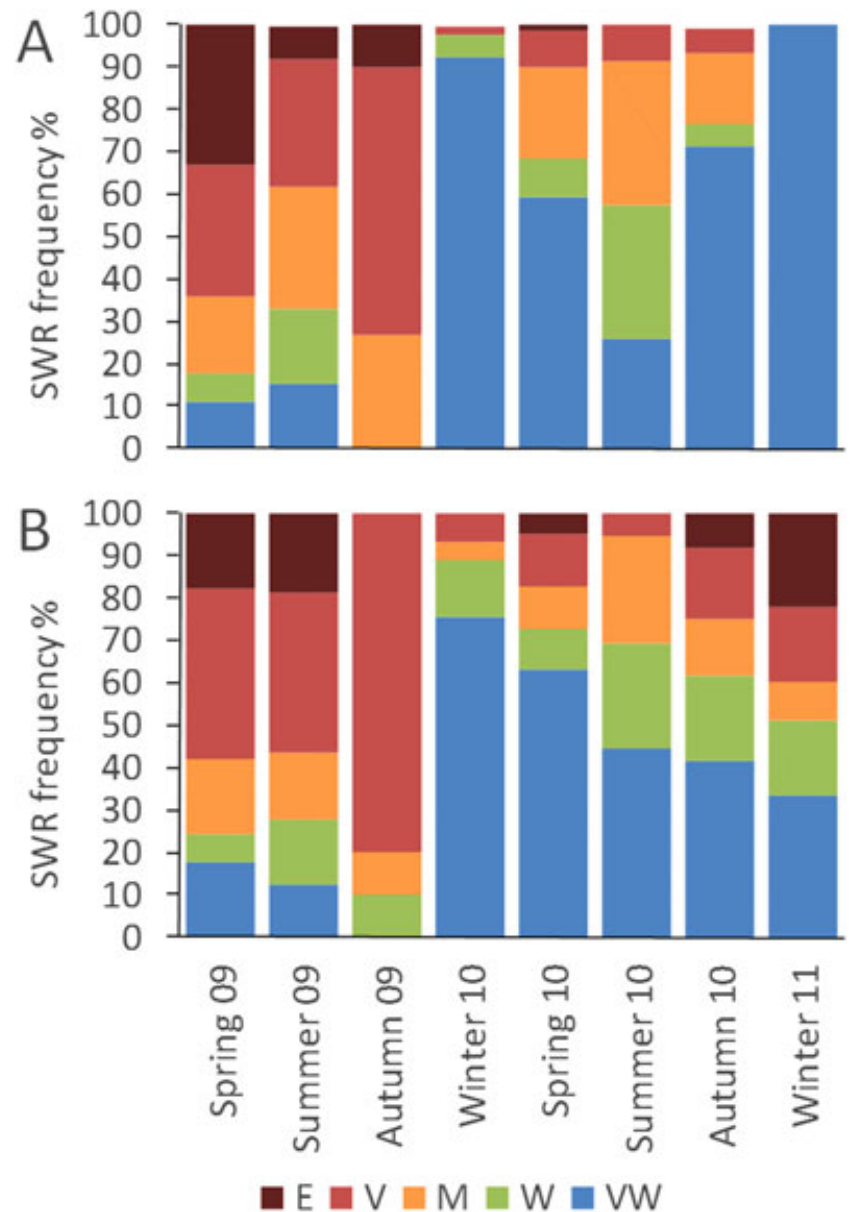

Figure 4. Frequency of seasonal soil water repellency in Pinus pinaster Ait. (A) and Eucalyptus globulus Labill (B) stands over 2009 and 2010, where E is extremely water repellent, $\mathrm{V}$ is very strong water repellent, $\mathrm{M}$ is moderate strong water repellent, $\mathrm{W}$ is wettable, and VW is very wettable.

the NSE did not indicate satisfactory performance in either case, although it increased from negative to positive values between runoff peak and total rates. Because the model had acceptable results in relative terms, poor NSE results are mostly related to the underestimation of the runoff peak and total runoff in four out of five events, with an average error of $-15 \%$ and $-31 \%$ respectively. Only event 20100610 approximated closely the measured runoff peak, while event 20101030 showed an overestimation of total runoff.

There were no noticeable differences for model performance between the TC-LAI and NDVI-LAI estimates; differences between those and the full cover estimate were only noticeable for the three larger storms, leading to further underestimation $(-18 \%$ for total runoff and $-32 \%$ for peak runoff). These differences did not lead to important changes to either the coefficient of determination or the NSE.

Looking closer at Figure 5A, the event of June 2009 (20090606) can be considered an outlier. The underestimation of this event coincided with the large extent of SWR during the summer of 2009 (Figure 4). Excluding this event markedly improved model performance in terms of runoff peak $\left(r^{2}=0.96\right.$ and NSE $\left.=0.87\right)$.

The event of December 2009 (20091230) can be considered an outlier when examining Figure 5B. LISEM strongly underestimated total runoff, despite low SWR during the winter of 2009. However, this event involved a relative high initial baseflow, which can be considered an indicator of the presence of extended saturated areas (Nunes et al., 2009; Beven, 2012). Excluding this event caused the model performance to improve in terms of predicting total runoff $\left(r^{2}=0.85\right.$ and $\left.\mathrm{NSE}=0 \cdot 31\right)$.

\section{Hydrograph Predictions}

Figure 6 provides a closer look at within-event model performance. LISEM performed considerably better for individual events than for overall model performance, with all events having $r^{2}$ and NSE above the thresholds for satisfactory or good model performance except for NSE in event 20090606. In fact, model performance was clearly worse for the two events during dry antecedent weather conditions (June 2009 and 2010) than for the three events under wet antecedent weather conditions. In event 20090606, LISEM was not able to simulate the high peak flow resulting from a relatively small storm (Figure 6A), while in event 20100610 LISEM was able to simulate the total and peak runoff but not the hydrograph shape (Figure 6D). As for the remaining events under wet conditions, all had $r^{2}$ and NSE above the threshold for good model performance
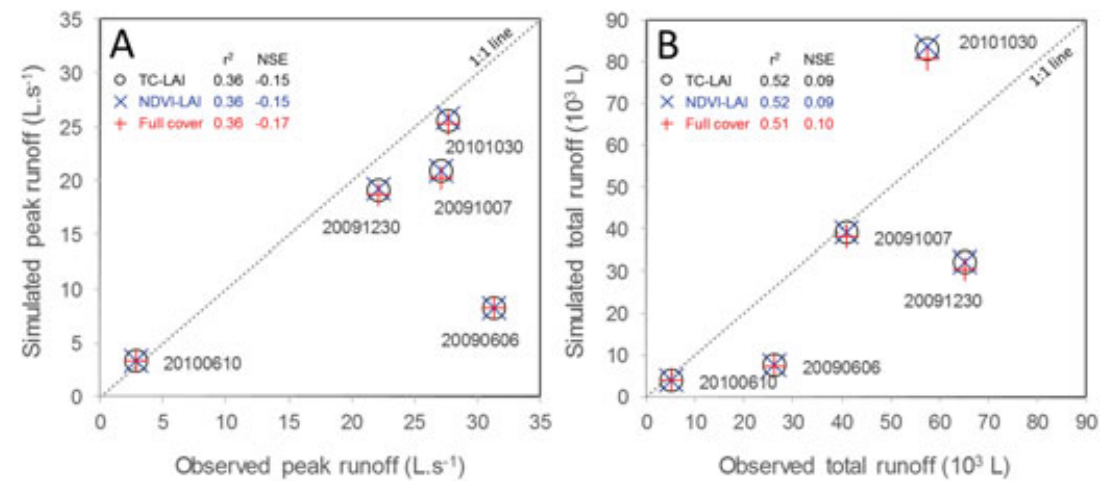

Figure 5. Overall model performance LISEM for total runoff (A) and peak runoff (B), evaluated with $r^{2}$ and NSE for TC-LAI relationship (black), NDVI-LAI relationship (blue), and full-cover scenario (red). 

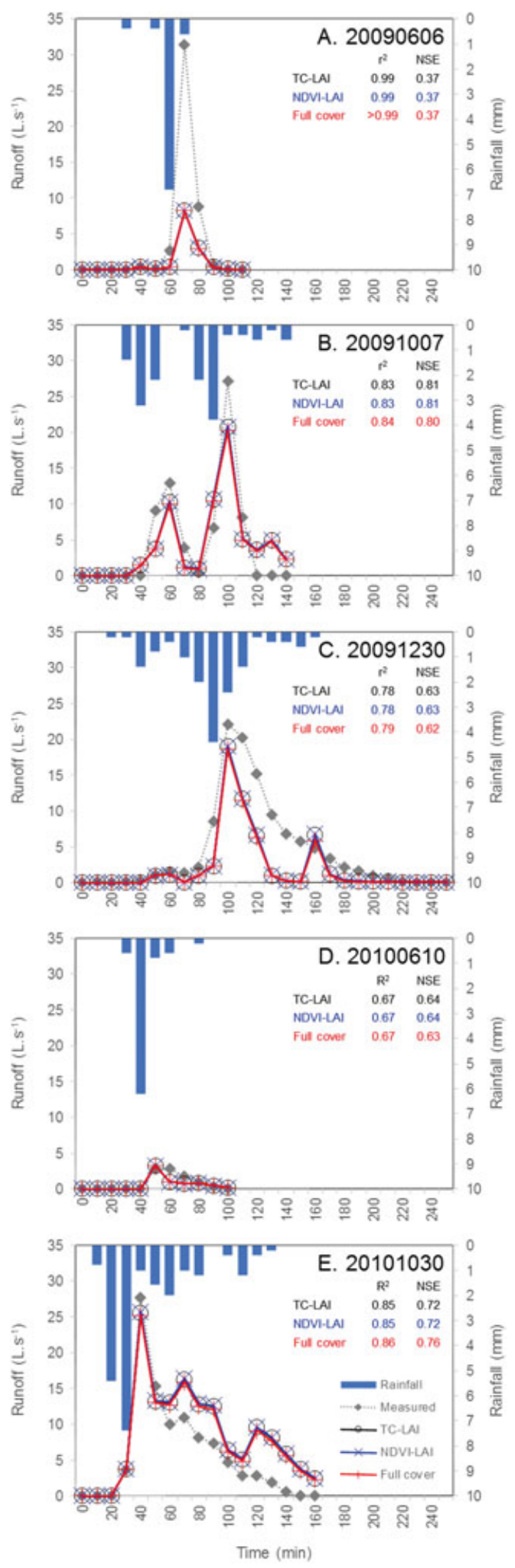

Figure 6. Within-model performance for events 20090606 (A), 20091007 (B), 20091230 (C), 20100610 (D), and 20091030 (E), evaluated with $r^{2}$ and NSE for TC-LAI relationship (black), NDVI-LAI relationship (blue), and full-cover scenario (red). although in event 20091230 (considered an outlier for total runoff) LISEM under-predicted flow rates throughout the entire event (Figure 6C).

The differences between TC-LAI, NDVI-LAI and full cover were even smaller than when considering total events. The only slightly noticeable impact was that of full cover for the longer rainfall events, resulting as a decrease in flow in peaks during the latter part of these storms (Figure 6B, C, and E). Changing LAI estimate had little impact on model performance, only being noticeable as a slight increase in NSE for event 20101030. The impacts of the full cover LAI in lowering total runoff were therefore mostly visible for accumulated event runoff.

\section{Impact of LAI Estimation Method}

Despite the differences between the NDVI-LAI and TC-LAI relationships (Figure 2), LISEM had an equal performance with both LAI inputs both at the event scale (Figure 5) and within events (Figure 6). Several explanations can be given for this outcome. First, the vegetation did not reach full cover in the monitoring period; LAI values ranged between 1 and 2, while full cover is close to 4 . The low vegetation cover led to relatively small interception losses; therefore, a more detailed input for LAI was prone to stay unnoticed by the model, as the fraction of change could be too small to have a noticeable effect on the total discharge. Second, even developed pine and eucalypt stands show relatively low interception losses, especially in stronger rainstorms (Valente et al., 1997), which would have additionally masked differences in LAI estimation methods. Third, vegetation management in the catchment limited the advantage that remotely sensed vegetation data might provide in terms of detecting heterogeneity in vegetation cover, something that usually is not easily captured by field point measurement data. Colmeal, with its main land use of eucalypt plantations, showed a rather homogeneous vegetation cover, which is also reflected in the similar ranges of TC-LAI and NDVI-LAI input values in Figure 2.

Finally, LISEM is less sensitive than similar models when simulating the impacts of vegetation on runoff, as shown by the model comparison study by Nearing et al. (2005). Therefore, the performance of LISEM in a post-fire scenario might be more dependent on soil related processes than on the interception capacity of the vegetation, which would limit the differentiation between the TC-LAI and NDVI-LAI estimation methods. In fact, LISEM only showed sensitivity to full cover LAI for the events with higher rainfall totals (Figure 5). The impact of higher LAI values, through higher interception storage capacity $S_{\max }$, was cumulative, and more noticeable as the event progressed and rainfall accumulated (Figure $6 \mathrm{~B}, \mathrm{C}$, and E), leading to slightly lower peaks. These arguments indicate that LISEM showed low sensitivity to vegetation cover, through a combination of low interception rates for plantation pines and eucalypts in Portugal (which the model correctly simulated) and low sensitivity of LISEM's interception module. This implies that vegetation cover data is not important for runoff modelling in burnt catchments, although it could be more important for erosion modelling. 
In this context, and based on the comparable results for TCLAI and NDVI-LAI, the NDVI-LAI relationship can be considered a substitute for ground-based LAI measurements for the monitoring of vegetation regeneration and, therefore, can facilitate the implementation of post-fire rainfall-runoff modelling in similar regions. While TC-LAI results can be easily monitored in the field because of the homogeneity of vegetation cover in plantations, NDVI-LAI offers a cheaper and easier alternative, also for analyses which are not started immediately after a fire. Moreover, it is possible that fires in a more heterogeneous environment in terms of vegetation cover (e.g. shrublands, natural growth forests) or with important variations of post-fire severity could allow NDVI-LAI to potentially improve modelled runoff response more than in the present study. Moreover, groundcover can vary with climatic region and forest management, making NDVI-LAI a suitable alternative for using literature values.

\section{Impact of SWR and Soil Moisture Conditions in Model Performance}

The general underestimation of the runoff peak and total runoff can be related to post-fire conditions in the catchment. The SWR data (Figure 4) showed that repellency was particularly severe during the first period after the wildfire, especially for the storms which occurred in 2009. LISEM underpredicted flows, especially peak flows, for the dry summer storm in June 2009 but not in July 2010, which can be related with the high summer SWR in 2009 but (unusually) low in 2010. Similarly, but less explicitly, LISEM underestimated flows for the storm in autumn 2009 under prevalent SWR conditions, but overestimated flows for the autumn 2010 storm when SWR was less prevalent (see Figure 2 and Figure 6). Not including SWR in models for this region, especially in burnt areas, usually leads to underestimating runoff generation (Vieira et al., 2014; Nunes et al., 2016), and therefore this could also explain the underestimation of flows in these conditions. In contrast, the underestimation for the storm in winter 2009 could be linked with the opposite problem, the presence of extensive saturated areas. Similar physically based models under similar circumstances are sensitive to high saturation conditions when modelling runoff (Nunes et al., 2009).

Overall, these results indicate that incorporating more information about soil moisture and their consequences, in particular SWR and saturation, would be more important than a correct representation of interception through LAI. Relatively simple approaches to address both issues have been proposed, from modifying soil water holding parameters in SWR (Vieira et al., 2014; Nunes et al., 2016) to using a topographic wetness index and antecedent baseflow to estimate the extent of saturated areas (Nunes et al., 2009); both could be tested in the future for the Colmeal catchment.

\section{CONCLUSIONS}

The Colmeal study area was monitored two years after a wildfire. Soil water repellency was strong in the first year, especially in the driest months, but declined after the first winter. Vegetation recovered quickly during the first year, and more slowly afterwards; eucalypts were close to recovered after two years. The LISEM model was tested for runoff predictions during this period. The model showed an acceptable performance for simulating relative differences between peak and total flows, but not for actual values. This could be attributed essentially to an underestimation of flow peaks when SWR was prevalent, and an underestimation of total flow when soil saturation could be expected. In contrast, LISEM showed little sensitivity to the interception simulation, which could be attributed both to the model itself and to the low interception rates of plantation forests in this region. The results indicate that LISEM is not sensitive to the methods used to introduce vegetation cover, and therefore the use of remote sensing could provide a cheap and reliable alternative for runoff simulation in burnt areas, potentially with added benefits when used for areas with heterogeneous vegetation cover or burn severity. In contrast, soil hydrological conditions, and in particular the presence of SWR and saturated areas, showed a higher impact, and future simulations of runoff in burn areas should include approaches to address them.

\section{ACKNOWLEDGEMENTS}

The authors thank Frans-Joost Boogert, Martinho Martins, and all the members of the ESP team at CESAM/UA for their help with the laboratory and field work. This research was funded by the Portuguese Foundation for Science and Technology through individual research grants attributed to J.P. Nunes (SFRH/BPD/87571/2012) and D.C.S. Vieira (SFRH/ $\mathrm{BD} / 65907 / 2009$ ), the EROSFIRE-II project (PTDC/AGRCFL/70968/2006), and funding for the CESAM centre (UID/AMB/50017), co-funded by the European Social Fund and the European Regional Development Fund within the PT2020 Partnership Agreement and Compete 2020. Additional funding was granted through COST (European Cooperation in Science and Technology) through Action ES1306 CONNECTEUR.

\section{REFERENCES}

Arnold JG, Allen PM, Muttiah R, Bernhardt G. 1995. Automated base flow separation and recession analysis techniques. Ground Water 33: 1010-1018. DOI:10.1111/j.1745-6584.1995.tb00046.x.

Aston AR. 1979. Rainfall interception by eight small trees. Journal of Hydrolology 42: 383-396.

Baret F, Guyot G. 1991. Potentials and limits of vegetation indices for LAI and APAR assessment. Remote Sensing of Environment 35: 161-173. DOI:10.1016/0034-4257(91)90009-U.

Beven KJ. 2012. Rainfall-runoff modelling: the primer, 2nd edn. WileyBlackwell: Hoboken.

Bisantino T, Bingner R, Chouaib W, Gentile F, Trisorio LG. 2015. Estimation of runoff, peak discharge and sediment load at the event scale in a mediumsize mediterranean watershed using the AnnAGNPS model. Land Degradation and Development 26: 340-355. DOI:10.1002/ldr.2213.

Bodí MB, Martin DA, Balfour VN, Santín C, Doerr SH, Pereira P, Cerdà A, Mataix-Solera J. 2014. Wildland fire ash: production, composition and eco-hydro-geomorphic effects. Earth-Science Reviews 130: 103-127. DOI:10.1016/j.earscirev.2013.12.007. 
Bodí MB, Muñoz-Santa I, Armero C, Doerr SH, Mataix-Solera J, Cerdà A. 2013. Spatial and temporal variations of water repellency and probability of its occurrence in calcareous Mediterranean rangeland soils affected by fires. Catena 108: 14-25. DOI:10.1016/j.catena.2012.04.002.

Borrelli P, Märker M, Schütt B. 2015. Modelling Post-Tree-Harvesting soil erosion and sediment deposition potential in the Turano river basin (Italian central apennine). Land Degradation and Development 26: 356-366. DOI:10.1002/ldr.2214

Campos I, Abrantes N, Vidal T, Bastos AC, Gonçalves F, Keizer JJ. 2012. Assessment of the toxicity of ash-loaded runoff from a recently burnt eucalypt plantation. European Journal of Forest Research 131: 1889-1903. DOI:10.1007/s10342-012-0640-7.

Certini G. 2005. Effects of fire on properties of forest soils: a review. Oecologia 143: 1-10. DOI:10.1007/s00442-004-1788-8.

Chander G, Markham B. 2003. Revised landsat-5 TM radiometrie calibration procedures and postcalibration dynamic ranges. IEEE Transactions on Geoscience and Remote Sensing 41: 2674-2677. DOI:10.1109/ TGRS.2003.818464

Chander G, Markham BL, Helder DL. 2009. Summary of current radiometric calibration coefficients for Landsat MSS, TM, ETM+, and EO-1 ALI sensors. Remote Sensing of Environment 113: 893-903. DOI:10.1016/j. rse.2009.01.007.

Chen L, Berli M, Chief K. 2013. Examining modeling approaches for the rainfall-runoff process in wildfire-affected watersheds: using San Dimas Experimental Forest. Journal of the American Water Resources Association 49: 851-866. DOI:10.1111/jawr.12043.

Chow VT, Maidment DR, Mays LW. 1988. Applied Hydrology. McGraw-Hill series in water resources and environmental engineering. McGraw-Hill: New York.

De la Rosa JM, Faria SR, Varela ME, Knicker H, González-Vila FJ, GonzálezPérez JA, Keizer J. 2012. Characterization of wildfire effects on soil organic matter using analytical pyrolysis. Geoderma 191: 24-30. DOI:10.1016/j. geoderma.2012.01.032.

De Roo APJ, Wesseling CG, Ritsema CJ. 1996. Lisem: a single-event physically based hydrological and soil erosion model for drainage basins. I: theory, input and output. Hydrological Processes 10: 1107-1117. DOI:10.1002/(SICI) 1099-1085(199608)10:8<1107::AID-HYP415>3.0.CO;2-4

Deguchi A, Hattori S, Park HT. 2006. The influence of seasonal changes in canopy structure on interception loss: application of the revised Gash model. Journal of Hydrology 318: 80-102. Retrieved from $<$ Go to ISI $>$ ://000235316500008.

Dingman SL. 2008. Physical hydrology, 2nd edn. Waveland Press: Long Grove.

Doerr S. 1998. Short communication on standardizing the 'water drop penetration time' and the 'molarity of an ethanol droplet' techniques to classify soil hydrophobicity: a case study using medium textured soils. Earth Surface Processes and Landforms 23: 663-668.

Doerr S, Shakesby R, Walsh R. 1996. Soil hydrophobicity variations with depth and particle size fraction in burned and unburned Eucalyptus globulus and Pinus pinaster forest terrain in the Águeda basin, Portugal. Catena 27: 25-47. DOI:10.1016/0341-8162(96)00007-0.

Doerr SH, Shakesby RA, Walsh RPD. 2000. Soil water repellency: its causes, characteristics and hydro-geomorphological significance. EarthScience Reviews 51: 33-65. DOI:10.1016/S0012-8252(00)00011-8.

Drake N, Vafeidis AT. 2004. Review of spatial and temporal methods for assessing land degradation in the Mediterranean. Advances in Environmental Monitoring and Modelling 1: 1-52.

Esteves TCJ, Kirkby MJ, Shakesby RA, Ferreira AJD, Soares JAA, Irvine BJ, Ferreira CSS, Coelho COA, Bento CPM, Carreiras MA. 2012. Mitigating land degradation caused by wild fire : application of the PESERA model to fire-affected sites in central Portugal. Geoderma 191: 40-50. DOI:10.1016/j.geoderma.2012.01.001.

Faria SR. 2009. Repelência à água dos Solos Florestais queimados e não queimados na região Centro de Portugal. University of Aveiro: Aveiro.

Ferreira AJD, Coelho COA, Boulet AK, Leighton-Boyce G, Keizer JJ, Ritsema CJ. 2005. Influence of burning intensity on water repellency and hydrological processes at forest and shrub sites in Portugal. Australian Journal of Soil Research 43: 327-336.

Ferreira AJD, Coelho COA, Ritsema CJ, Boulet AK, Keizer JJ. 2008. Soil and water degradation processes in burned areas: lessons learned from a nested approach. Catena 74: 273-285. DOI:10.1016/j.catena.2008.05.007.

Ferreira AJD, Prats Alegre S, Coelho COA, Shakesby RA, Páscoa FM, Ferreira CSS, Keizer JJ, Ritsema C. 2015. Strategies to prevent forest fires and techniques to reverse degradation processes in burned areas. Catena 128: 224-237. DOI:10.1016/j.catena.2014.09.002.
Hoff C, Rambal S, Joffre R. 2002. Simulating carbon and water flows and growth in a Mediterranean evergreen Quercus ilex coppice using the FOREST-BGC model. Forest Ecology and Management 164: 121-136. DOI:10.1016/S0378-1127(01)00605-3

Hoyningen-Huene J v. 1983. Die Interzeption des Niederschlages in landwirtschaftlichen Pflanzenbeständen (p. 153). Verlag Paul Parey: Hamburg/Berlin.

Jonckheere I, Fleck S, Nackaerts K, Muys B, Coppin P, Weiss M, Baret F. 2004. Review of methods for in situ leaf area index determination Part I. Theories, sensors and hemispherical photography. Agricultural and Forest Meteorology 121: 19-35. DOI:10.1016/j. agrformet.2003.08.027.

Keesstra SD, Bruijnzeel LA, van Huissteden J. 2009. Meso-scale catchment sediment budgets: combining field surveys and modeling in the Dragonja catchment, southwest Slovenia. Earth Surface Processes and Landforms 34: 1547-1561. DOI:10.1002/esp.1846.

Keesstra SD, Maroulis J, Argaman E, Voogt A, Wittenberg L. 2014. Effects of controlled fire on hydrology and erosion under simulated rainfall. Cuadernos de Investigación Geográfica 40: 269-293. DOI: 10.18172/cig.2532.

Keizer JJ, Coelho COA, Matias MJS, Domingues CSP, Ferreira AJD. 2005 Soil water repellency under dry and wet antecedent weather conditions for selected land-cover types in the coastal zone of central Portugal. Australian Journal of Soil Research 43: 297-308.

Keizer JJ, Doerr SH, Malvar MC, Prats SA, Ferreira RSV, Oñate MG, Coelho COA, Ferreira AJD. 2008. Temporal variation in topsoil water repellency in two recently burnt eucalypt stands in north-central Portugal. Catena 74: 192-204. DOI:10.1016/j.catena.2008.01.004.

Lillesand TM, Kiefer RW, Chipman JW. 2008. Remote sensing and image interpretation. John Wiley and sons: Hoboken.

Maia P, Pausas JG, Arcenegui V, Guerrero C, Pérez-Bejarano A, Mataix-Solera J, Varela MET, Fernandes I, Pedrosa ET, Keizer JJ. 2012. Wildfire effects on the soil seed bank of a maritime pine stand-the importance of fire severity. Geoderma 191: 80-88. DOI:10.1016/j.geoderma.2012.02.001.

Malvar MC, Martins MAS, Nunes JP, Robichaud PR, Keizer JJ. 2013. Assessing the role of pre-fire ground preparation operations and soil water repellency in post-fire runoff and inter-rill erosion by repeated rainfall simulation experiments in Portuguese eucalypt plantations. Catena 108 69-83. DOI:10.1016/j.catena.2012.11.004.

Malvar MC, Prats SA, Nunes JP, Keizer JJ. 2011. Post-fire overland flow generation and inter-rill erosion under simulated rainfall in two eucalypt stands in north-central Portugal. Environmental Research 111: 222-36. DOI:10.1016/j.envres.2010.09.003.

Malvar MC, Prats SA, Nunes JP, Keizer JJ. 2015. Soil water repellency severity and its spatio-temporal variation in burnt eucalypt plantations in north-central Portugal. Land Degradation \& Development. DOI:10.1002/ldr.2450.

Mataix-Solera J, Cerdà A, Arcenegui V, Jordán A, Zavala LM. 2011. Fire effects on soil aggregation: a review. Earth-Science Reviews 109 44-60. DOI:10.1016/j.earscirev.2011.08.002.

Mayor AG, Bautista S, Llovet J, Bellot J. 2007. Post-fire hydrological and erosional responses of a Mediterranean landscape: seven years of catchmentscale dynamics. Catena 71: 68-75. DOI:10.1016/j.catena.2006.10.006.

Moody JA, Shakesby RA, Robichaud PR, Cannon SH, Martin DA. 2013. Current research issues related to post-wildfire runoff and erosion processes. Earth-Science Reviews 122: 10-37. DOI:10.1016/j.earscirev.2013.03.004.

Morrison KD, Kolden CA. 2015. Modeling the impacts of wildfire on runoff and pollutant transport from coastal watersheds to the nearshore environment. Journal of Environmental Management 151: 113-123. DOI:10.1016/j.jenvman.2014.12.025.

Motovilov YG, Gottschalk L, Engeland K, Rodhe A. 1999. Validation of a distributed hydrological model against spatial observations. Agricultural and Forest Meteorology 98-99: 257-277.

Moussoulis E, Mallinis G, Koutsias N, Zacharias I. 2015. Modelling surface runoff to evaluate the effects of wildfires in multiple semi-arid, shrubland-dominated catchments. Hydrological Processes 29: 4427-4441. DOI:10.1002/hyp.10509.

Nearing MA, Jetten V, Baffaut C, Cerdan O, Couturier A, Hernandez M, Le Bissonnais Y, Nichols MH, Nunes JP, Renschler CS, Souchere V, van Oost K. 2005. Modeling response of soil erosion and runoff to changes in precipitation and cover. Catena 61: 131-154. DOI: DOI 10.1016/j. catena.2005.03.007

Nunes JP, Malvar M, Benali AA, Rial Rivas ME, Keizer JJ. 2016. A simple water balance model adapted for soil water repellency: application on Portuguese burned and unburned eucalypt stands. Hydrological Processes 30: 463-478. DOI:10.1002/hyp.10629.

Nunes JP, Seixas J, Keizer JJ. 2013. Modeling the response of within-storm runoff and erosion dynamics to climate change in two Mediterranean 
watersheds: a multi-model, multi-scale approach to scenario design and analysis. Catena 102: 27-39. DOI:10.1016/j.catena.2011.04.001.

Nunes JP, Seixas J, Keizer JJ, Ferreira AJD. 2009. Sensitivity of runoff and soil erosion to climate change in two Mediterranean watersheds. Part I: model parameterization and evaluation. Hydrological Processes 23: 1202-1211. DOI:10.1002/hyp.7247.

Otero M, Santos D, Barros AC, Calapez P, Maia P, Keizer JJ, Esteves VI, Lillebo AI. 2015. Soil properties, phosphorus fractions and sorption after wildfire in north-central Portugal. Geoderma Regional 5: 86-95. DOI:10.1016/j.geodrs.2015.04.003.

Prats SA, Malvar MC, Vieira DCS, MacDonald L, Keizer JJ. 2013. Effectiveness of hydromulching to reduce runoff and erosion in a recently burnt pine plantation in central Portugal. Land Degradation \& Development . DOI:10.1002/ldr.2236.

Prats SA, Wagenbrenner JW, Martins MAS, Malvar Cortizo M, Keizer JJ. 2015. Hydrologic implications of post-fire mulching across different spatial scales. Land Degradation and Development. DOI:10.1002/ldr.2422.

Rawls WJ, Brakensiek DL, Saxton KE. 1982. Estimation of soil water properties. Transactions of the ASAE.

Santos JM, Verheijen FGA, Tavares Wahren F, Wahren A, Feger K-H, Bernard-Jannin L, Rial-Rivas ME, Keizer JJ, Nunes JP. 2013. Soil water repellency dynamics in pine and eucalypt plantations in Portugal-a high-resolution time series. Land Degradation \& Development. DOI:10.1002/ldr.2251.

Saxton KE, Rawls WJ. 2006. Soil water characteristic estimates by texture and organic matter for hydrologic solutions. Soil Science Society of America Journal 70: 1569-1578. DOI:10.2136/sssaj2005.0117.

Scurlock JMO, Asner GP, Gower ST. 2001. Global leaf area index from field measurements, 1932-2000.

Shakesby RA. 2011. Post-wildfire soil erosion in the Mediterranean: review and future research directions. Earth-Science Reviews 105: 71-100. DOI:10.1016/j.earscirev.2011.01.001.

Shakesby RA, Doerr SH. 2006. Wildfire as a hydrological and geomorphological agent. Earth-Science Reviews 74: 269-307. DOI:10.1016/j. earscirev.2005.10.006.

Soto BB, Díaz-Fierros F. 1998. Runoff and soil erosion from areas of burnt scrub : comparison of experimental results with those predicted by the WEPP model. Catena 31: 257-270. DOI:10.1016/S0341-8162(97)00047-7.
Tessler N, Wittenberg L, Malkinson D, Greenbaum N. 2008. Fire effects and short-term changes in soil water repellency-Mt. Carmel, Israel. Catena 74: 185-191. DOI:10.1016/j.catena.2008.03.002.

Vafeidis AT, Drake NA, Wainwright J. 2007. A proposed method for modelling the hydrologic response of catchments to burning with the use of remote sensing and GIS. Catena 70: 396-409. DOI:10.1016/j. catena.2006.11.008.

Valente F, David JS, Gash JHC. 1997. Modelling interception loss for two sparse eucalypt and pine forests in central Portugal using reformulated Rutter and Gash analytical models. Journal of Hydrology 190: 141-162. DOI:10.1016/S0022-1694(96)03066-1.

Valentini R, Gamon JA, Field CB. 1995. Ecosystem gas exchange in a California grassland: seasonal patterns and implications for scaling. Ecology 76: 1940-1952. DOI:10.2307/1940725.

Van Leeuwen WJD, Casady GM, Neary DG, Bautista S, Alloza JA, Carmel Y, Wittenberg L, Malkinson D, Orr BJ. 2010. Monitoring post-wildfire vegetation response with remotely sensed time-series data in Spain, USA and Israel. International Journal of Wildland Fire 19: 75-93. DOI:10.1071/WF08078.

Viedma O, Meliá J, Segarra D, García-Haro J. 1997. Modeling rates of ecosystem recovery after fires by using landsat TM data. Remote Sensing of Environment 61: 383-398. DOI:10.1016/S0034-4257(97)00048-5.

Vieira DCS. 2015. Understanding and modelling hydrological and soil erosion processes in burnt forest catchments. University of Aveiro.

Vieira DCS, Fernández C, Vega JA, Keizer JJ. 2015. Does soil burn severity affect the post-fire runoff and interrill erosion response? A review based on meta-analysis of field rainfall simulation data. Journal of Hydrology: Aveiro. 523: 452-464. DOI:10.1016/j.jhydrol.2015.01.071.

Vieira DCS, Prats SA, Nunes JP, Shakesby RA, Coelho COA, Keizer JJ. 2014. Modelling runoff and erosion, and their mitigation, in burned Portuguese forest using the revised Morgan - Morgan - Finney model. Forest Ecology and Management 314: 150-165. DOI:10.1016/j. foreco.2013.12.006.

Vogelmann JE, Kost JR, Tolk B, Howard S, Short K, Chen X, Huang C, Pabst K, Rollins MG. 2011. Monitoring landscape change for LANDFIRE using multi-temporal satellite imagery and ancillary data. IEEE Journal of Selected Topics in Applied Earth Observations and Remote Sensing 4: 252-264. DOI:10.1109/JSTARS.2010.2044478. 